\title{
Assessing the Representativeness of Data on Yield Losses Due to Rice Diseases in Tropical Asia
}

\author{
Serge Savary, Plant Pathologist and ORSTOM Visiting Scientist, F. A. Elazegui, Associate Scientist, and Paul S. \\ Teng, Plant Pathologist, Entomology and Plant Pathology Division, International Rice Research Institute, P.O. Box \\ 933, 1099 Manila, Philippines
}

\begin{abstract}
Savary, S., Elazegui, F. A., and Teng, P. S. 1998. Assessing the representativeness of data on yield losses due to rice diseases in tropical Asia. Plant Dis. 82:705-709.

The representativeness of information on yield losses due to rice diseases in tropical Asia was studied. Published studies involving different groups of diseases (viral, bacterial, and fungal) and conducted in different rice production ecosystems were compared to help identify research gaps, the filling of which could improve current disease management in rice and help in developing strategies that fit the management needs of fast-evolving rice production systems in the future. Four criteria of representativeness of yield loss information were used: representativeness over time (the proportion of studies conducted over more than one crop cycle), representativeness over space (the proportion of studies conducted in more than one location), representativeness of scale (the proportion of studies conducted on the scale of plots or fields), and representativeness of injury (the standard deviation of the proportion of studies using inoculation, spontaneous infection, or chemical control). A strong imbalance in both the number and the representativeness of studies dealing with fungal, viral, and bacterial diseases was found. Most of the few studies of yield loss due to viral diseases (mainly rice tungro disease) were conducted on the scale of individual (potted) plants or were based on one-year data sets, often reflecting strong epidemics only. Studies of bacterial diseases were conducted in single locations only, and whether such results can be extrapolated still needs to be addressed. There is an acute need to better document yield losses in rice ecosystems other than the irrigated ecosystem. While studies conducted in the upland, rain-fed lowland, and deep-water rice ecosystems seem to have a high degree of representativeness, this cannot compensate for their small number in view of the great diversity of these environments. Studies of irrigated rice tend to concentrate on one year and one location. This approach may be based on the erroneous view that the irrigated ecosystem is homogeneous, and possible extrapolation of data from these studies needs to be examined.
\end{abstract}

The economic, social, and political importance of rice production for Asia today and for its future development is well known $(15,16)$ : Asia supports roughly $60 \%$ of the world's population; the area used for rice production in Asia accounts for $90 \%$ of the global total; and rice is the staple food of half of the world's population. The region has seen important changes in ricecropping practices over the past three decades, which reflect to a large extent efforts of agricultural research to avert food shortages $(14,16)$. It is widely recognized that Asia's rice-based agricultural systems will have to undergo considerable transformations in the future to reconcile the needs

Corresponding author: S. Savary

E-mail: s.savary@cgnet.com

Accepted for publication 2 February 1998.

Publication no. D-1998-0330-01S

(C) 1998 The American Phytopathological Society of a still-expanding population, most of which will live in cities, and to safeguard shrinking agricultural resources $(2,16)$.

Four broad rice ecosystems have been distinguished in Asia (5): upland, in which rice is seeded in nonflooded, well-drained soils; rain-fed lowland, in which rice is transplanted or seeded in bunded fields with variable depth and duration of flooding; deep-water, in which rice is seeded or transplanted in fields subject to deep flooding (50 to more than $300 \mathrm{~cm}$ ); and irrigated, in which rice is transplanted or seeded on leveled, bunded fields with water control. The irrigated ecosystem is the most productive environment for rice, but it is exposed to major and increasing constraints (the reduction of available land, shrinking availability of water, and labor shortages) and will have to rely on lower nitrogen fertilizer, herbicide, and pesticide inputs while maintaining its productivity. The other three ecosystems represent different degrees of opportunity for increasing rice production in Asia through various intensification processes while maintaining environmental resources.
Accurate quantitative information on yield losses due to diseases is necessary in order to develop policies, set research priorities, assess the progress made in protecting crops, and develop efficient integrated pest management schemes (22). Such information represents Level 1 of a process leading to the implementation of a systems approach in disease management (17). Variations in cropping practices are known to have a strong influence on crop pest profiles and, therefore, on the relative importance of diseases $(10,17)$. Data on yield losses due to diseases are thus necessary when agricultural systems are undergoing rapid and important transformations, as the rice-based cropping systems of tropical Asia are, so that the risks associated with such changes can be assessed from a plant protection viewpoint (11).

This article attempts to provide an overview of the methodologies that have been used over the past three decades to measure yield losses due to rice diseases in tropical Asia. Our objectives were i) to describe differences in methods used to study various rice diseases, ii) to detect discrepancies in research efforts devoted to the various rice ecosystems, and iii) to identify research gaps and future needs for information on yield losses due to rice diseases.

\section{Literature Search}

Publications from the period 1960-1993 dealing with crop losses ascribed to rice diseases were searched. Ideally, crop loss studies should be conducted in more than one location and for more than one year, should involve the major cultivars grown by farmers, and should involve several levels of disease injury (7). Published studies were selected on the following criteria: i) the measurement of yield loss was one of their main objectives, ii) they described their experimental and sampling designs, iii) they described the techniques used to manipulate disease levels (if applicable) and measure yield variation, and iv) they provided quantitative information on yield losses. A series of 108 studies of viral, bacterial, and fungal diseases was selected. Studies of rice yield loss due to insect injuriess were also included in the analysis, to allow comparisons between phytopathological and entomological research. 


\section{Criteria for Classifying Reports}

Information used to classify each published report included the duration of the study, the number of locations involved, the scale (from individual plants to whole fields) considered in assessments of yield losses, and the techniques used to manipulate pathogens. This information was then translated into criteria that allowed an assessment of the representativeness of the information provided by each study with respect to space, time, scale, and injury.

Representativeness over time. Representativeness over time implies that information is not biased and does not pertain only to a particular year when a major epidemic occurred. Putter (8) proposed that endemicity is one key characteristic of tropical pathosystems. While this is an appealing concept for traditional subsistence agriculture, it does not seem to apply to rice production in many areas of Asia, where epidemics occur sporadically (19). James (3) recommended that a crop loss study cover a period of at least 3 years. Studies considered for this report were classified as having been conducted for 1 year, 2 years, or more than 2 years.

Representativeness over space. Geographical location can have strong consequences for disease dynamics (e.g., effects due to local climatic conditions), injury (e.g., effects due to site-specific factors influencing host physiology and its interaction with the pathogen), and yield loss. Ideally, the same experiment should be conducted in all geographical areas where the crop is important (3). Studies considered for this report were classified as having been conducted in one location or in more than one location.

Representativeness of scale. The scale on which crop loss is assessed (individual plants, plots, or whole fields) is crucial to the representativeness of the data. One useful guideline in choosing an appropriate scale is to consider the number of yield components needed to explain yield variation (18). The single-tiller or single-plant technique has been advocated for cereal crops because i) it can provide data on a large range of disease intensities, ii) it saves labor and land, compared to plot techniques, iii) it does not require the use of biocides to establish disease levels, and iv) it leads to higher precision in estimating the slopes of regression lines of yield loss on disease (13). This approach, however, does not address the system where yield builds up, i.e., a plant stand in which interactions between plants occur dynamically, nor does it allow consideration of crop husbandry practices, i.e., factors that determine the attainable yield of a crop $(12,21)$. The experimental plot approach has several drawbacks, including the possibility that interplot interference may reduce the representativeness of disease and yield measurements (20) and the occurrence of within-plot spatial heterogeneity. The choice of plot size and plot isolation is a matter of the skill and anticipation of the experimenter, who has to consider the spatio-temporal characteristics of the pathosystem (the disease may develop in foci or not; it may spread more or less easily), inherent attributes of the crop (e.g., plant geometry), and characteristics of the experimental area (e.g., soil homogeneity) (9). Studies of yield losses due to rice diseases were grouped in four categories of increasing scale: individual plants, small plots (less than $1 \mathrm{~m}^{2}$ ), large plots, and whole fields.

Representativeness of injury. An additional criterion considered in the analysis was the technique used to establish disease levels. Methods of generating different levels of disease epidemics in crop loss experiments were reviewed by Sah and MacKenzie (9). Rice diseases vary in the ease with which they can be manipulated, and three groups were considered here, including studies involving inoculation, studies relying on spontaneous infection, and studies in which biocides were used to manipulate disease levels. The availability of an inoculation technique allows the establishment of a range of disease injuries. One drawback of some inoculation techniques is that they may not reflect natural infection processes and the resulting injuries. Relying on spontaneous infection ensures representativeness of injuries, but it implies that only a limited range of injury levels can be considered. Often, such studies have to rely partly on biocides to generate different disease levels. Studies that rely only on spontaneous infection may also be conducted in years when major epidemics occur and thus lack representativeness of disease level over time. Studies that rely primarily on biocides have the potential to address a wide range of disease levels. Very often, however, this range depends on the level of spontaneous infection. In addition, biocides may affect other pathogens (and lead to confounded results) or antagonists of the pathogen under study, or they may influence the physiology of the host and its yield, thus reducing the representativeness of yield loss data. In practice, there does not seem to be one ideal method for all diseases. Rather, a combination of techniques is often desirable (9), especially when several diseases are considered simultaneously $(4,12)$. There are very few studies of yield losses due to combinations of harmful agents (6) in the rice literature.

\section{Data Analysis}

Assessments of the representativeness of data on yield losses due to rice diseases over time, space, and scale were based on the proportion of studies conducted over more than 1 year, the proportion of studies conducted in more than one location, and the proportion of studies conducted on the scale of large plots (larger than $1 \mathrm{~m}^{2}$ ) or whole fields, respectively. Representativeness of injury was judged much more difficult to assess, as all methods have advantages and drawbacks, whose importance may vary depending on the pathosystem considered. An index to assess the representativeness of yield loss information was sought. Instead of ranking categories, the standard deviation of the proportion of studies using inoculation, spontaneous infection, or chemical control was used. A low standard deviation in one group of studies (e.g., yield losses due to bacterial leaf blight) would indicate the availability of varied options, flexibility in addressing a particular issue, and a balance among approaches and results.

A first set of comparisons was based on the nature of the harmful agent. Studies were grouped according to the causal agents of the diseases under consideration (viruses, bacteria, and fungi), and these groups of studies were compared with respect to their representativeness. A group of entomological studies was also included in the comparison. A few representative diseases were considered separately within each group to illustrate comparisons. Second, studies were grouped according to the rice ecosystem under consideration and compared with respect to representativeness. This comparison was aimed at identifying specific gaps where information on yield loss will be needed to develop future research for disease management.

\section{Results}

Studies grouped according to causal agent were compared with respect to their duration, number of locations, scale, and injury manipulation techniques used (Tables 1-4). The number of studies in each comparison varied, as information pertaining to each criterion could not always be obtained from each study. Overall, many more studies of yield losses were devoted to fungi than to bacteria or viruses.

There was a sharp contrast between disease groups with respect to the time span of crop loss studies (Table 1). Many studies of fungal diseases covered more than 2 years, while studies of bacterial diseases lasted 2 years at most, and all studies of viral diseases used data from one season only.

Many studies of viral diseases (which are often survey-like studies) and fungal diseases were conducted at several locations (Table 2), whereas studies of yield losses caused by bacterial diseases were conducted at one location.

Studies of viral diseases were predominantly on a small scale (involving individual plants or small plots) rather than a large scale (involving large plots or fields), whereas studies of bacterial diseases were conducted on small and large scales equally, and studies of fungal diseases were predominantly on the scale of large plots or whole fields (Table 3). 
Studies of fungal diseases mostly relied on inoculation or spontaneous infection for injury manipulation, and few of them used chemical control (Table 4). Studies of bacterial and viral diseases were based on inoculation or spontaneous infection only.

Comparison of representativeness (Table 5 ) indicates that the information available on yield losses due to fungi generally ranks better with respect to time, scale, and injury than information on yield losses due to bacteria and viruses. The weakness of the information on yield losses due to virus diseases appears to be representativeness over time and, to some extent, representativeness of scale. Information on yield losses due to bacterial diseases seems to be weak in representativeness over space, and it possibly reflects a lack of flexibility in the availability of methods of manipulating injuries. Phytopathological studies, as a whole, appear to have a lower representativeness than entomological ones.

Considerable discrepancies exist between yield loss studies in the different rice production ecosystems. Most studies were conducted in the irrigated ecosystem, while few considered other ecosystems. A large proportion of the studies in the irrigated ecosystem were conducted in one season only, while many studies in the three other ecosystems were conducted in at least two seasons (Table 6). Most studies in the irrigated ecosystem were conducted in only one location, while many studies in the other three ecosystems were conducted at several locations (Table 7). Large plots and whole fields appear to be the predominant scales used, especially in the rain-fed lowland, deep-water, and upland ecosystems (Table 8). The techniques used to manipulate injuries were similar among the four ecosystems (Table 9).

Representativeness over time thus appears to be higher in the upland, deepwater, and rain-fed lowland ecosystems than in the irrigated ecosystem (Table 10). Studies in the irrigated ecosystem seem to have a lower representativeness over space as well. Studies in the deep-water ecosystem appear to have a particularly high representativeness of scale (Table 10). The four ecosystems do not appear to differ with respect to representativeness of injury.

\section{Discussion}

There is a large body of literature addressing yield losses due to rice diseases (19). The criteria used to select published studies in this analysis, especially the requirement that each one should have yield loss assessment as a main objective, were such that the list of studies used in these comparisons is not comprehensive. This overview of literature on assessment of yield loss due to rice diseases, however, indicates that there is considerable room for improvement in representativeness. Comparison of phytopathological and entomological studies also suggests a need to generate more information on yield losses due to rice diseases. There appears to be a strong imbalance in both the number and the representativeness of studies of fungal diseases on the one hand and studies of viral and bacterial diseases on the other hand. This seems to reflect differences in methodological traditions (mycologists be-

Table 1. Number of studies of crop losses due to different groups of rice diseases and insect pests in tropical Asia, classified by time span

\begin{tabular}{|c|c|c|c|c|c|c|c|c|c|c|c|}
\hline \multirow[b]{2}{*}{$\begin{array}{l}\text { Duration of } \\
\text { experiments }\end{array}$} & \multicolumn{2}{|c|}{ Bacterial diseases } & \multicolumn{4}{|c|}{ Fungal diseases } & \multicolumn{2}{|c|}{ Viral diseases } & \multicolumn{3}{|c|}{ Insect injuries } \\
\hline & Total & $\begin{array}{l}\text { Bacterial } \\
\text { leaf blight }\end{array}$ & Total & $\begin{array}{l}\text { Leaf } \\
\text { blast }\end{array}$ & $\begin{array}{c}\text { Neck blast, } \\
\text { panicle blast }\end{array}$ & $\begin{array}{c}\text { Sheath } \\
\text { blight }\end{array}$ & Total & Tungro & Total & $\begin{array}{c}\text { Leaf } \\
\text { folders }\end{array}$ & $\begin{array}{c}\text { Stem } \\
\text { borers }\end{array}$ \\
\hline One season & 4 & 3 & 14 & 0 & 2 & 3 & 6 & 4 & 16 & 5 & 6 \\
\hline Two seasons & 4 & 3 & 11 & 3 & 3 & 3 & 0 & 0 & 5 & 1 & 4 \\
\hline More than two seasons & 1 & 1 & 11 & 3 & 4 & 2 & 0 & 0 & 24 & 6 & 10 \\
\hline
\end{tabular}

Table 2. Number of studies of crop losses due to different groups of rice diseases and insect pests in tropical Asia, classified by the number of locations studied

\begin{tabular}{|c|c|c|c|c|c|c|c|c|c|c|c|}
\hline \multirow[b]{2}{*}{$\begin{array}{l}\text { Number } \\
\text { of locations }\end{array}$} & \multicolumn{2}{|c|}{ Bacterial diseases } & \multicolumn{4}{|c|}{ Fungal diseases } & \multicolumn{2}{|c|}{ Viral diseases } & \multicolumn{3}{|c|}{ Insect injuries } \\
\hline & Total & $\begin{array}{c}\text { Bacterial } \\
\text { leaf blight }\end{array}$ & Total & $\begin{array}{l}\text { Leaf } \\
\text { blast }\end{array}$ & $\begin{array}{c}\text { Neck blast, } \\
\text { panicle blast }\end{array}$ & $\begin{array}{c}\text { Sheath } \\
\text { blight }\end{array}$ & Total & Tungro & Total & $\begin{array}{c}\text { Leaf } \\
\text { folders }\end{array}$ & $\begin{array}{c}\text { Stem } \\
\text { borers }\end{array}$ \\
\hline One location & 9 & 7 & 25 & 4 & 6 & 8 & 3 & 1 & 20 & 5 & 7 \\
\hline More than one location & 0 & 0 & 11 & 2 & 3 & 0 & 3 & 3 & 25 & 7 & 13 \\
\hline
\end{tabular}

Table 3. Number of studies of crop losses due to different groups of rice diseases and insect pests in tropical Asia, classified by the scale of experiments

\begin{tabular}{|c|c|c|c|c|c|c|c|c|c|c|c|}
\hline \multirow[b]{2}{*}{ Scale } & \multicolumn{2}{|c|}{ Bacterial diseases } & \multicolumn{4}{|c|}{ Fungal diseases } & \multicolumn{2}{|c|}{ Viral diseases } & \multicolumn{3}{|c|}{ Insect injuries } \\
\hline & Total & $\begin{array}{c}\text { Bacterial } \\
\text { leaf blight }\end{array}$ & Total & $\begin{array}{l}\text { Leaf } \\
\text { blast }\end{array}$ & $\begin{array}{c}\text { Neck blast, } \\
\text { panicle blast }\end{array}$ & $\begin{array}{c}\text { Sheath } \\
\text { blight }\end{array}$ & Total & Tungro & Total & $\begin{array}{c}\text { Leaf } \\
\text { folders }\end{array}$ & $\begin{array}{c}\text { Stem } \\
\text { borers }\end{array}$ \\
\hline One plant or hill & 4 & 3 & 12 & 3 & 2 & 1 & 4 & 3 & 12 & 4 & 6 \\
\hline Small plot $\left(<1 \mathrm{~m}^{2}\right)$ & 1 & 1 & 3 & 1 & 0 & 1 & 1 & 1 & 0 & 0 & 0 \\
\hline Large plot $\left(>1 \mathrm{~m}^{2}\right)$ & 5 & 4 & 23 & 4 & 6 & 8 & 1 & 0 & 35 & 8 & 15 \\
\hline Whole field & 0 & 0 & 0 & 0 & 0 & 0 & 1 & 1 & 2 & 1 & 1 \\
\hline
\end{tabular}

Table 4. Number of studies of crop losses due to different groups of rice diseases and insect pests in tropical Asia, classified by methods of injury manipulation

\begin{tabular}{|c|c|c|c|c|c|c|c|c|c|c|c|}
\hline \multirow[b]{2}{*}{$\begin{array}{l}\text { Method of injury } \\
\text { manipulation }\end{array}$} & \multicolumn{2}{|c|}{ Bacterial diseases } & \multicolumn{4}{|c|}{ Fungal diseases } & \multicolumn{2}{|c|}{ Viral diseases } & \multicolumn{3}{|c|}{ Insect injuries } \\
\hline & Total & $\begin{array}{l}\text { Bacterial } \\
\text { leaf blight }\end{array}$ & Total & $\begin{array}{l}\text { Leaf } \\
\text { blast }\end{array}$ & $\begin{array}{c}\text { Neck blast, } \\
\text { panicle blast }\end{array}$ & $\begin{array}{c}\text { Sheath } \\
\text { blight }\end{array}$ & Total & Tungro & Total & $\begin{array}{c}\text { Leaf } \\
\text { folders }\end{array}$ & $\begin{array}{c}\text { Stem } \\
\text { borers }\end{array}$ \\
\hline Inoculation & 7 & 6 & 18 & 5 & 3 & 8 & 3 & 2 & $13^{\mathrm{a}}$ & 3 & 6 \\
\hline Spontaneous infection & 3 & 2 & 17 & 2 & 4 & 1 & 4 & 3 & 14 & 3 & 7 \\
\hline Chemical control & 0 & 0 & 3 & 0 & 2 & 0 & 0 & 0 & 19 & 7 & 9 \\
\hline
\end{tabular}

${ }^{a}$ Artificial infestation with insects. 
Table 5. Representativeness of studies of crop losses due to different groups of rice diseases and insect pests in tropical Asia

\begin{tabular}{lcccc}
\hline $\begin{array}{l}\text { Representativeness } \\
\text { criterion }\end{array}$ & $\begin{array}{c}\text { Bacterial } \\
\text { diseases }\end{array}$ & $\begin{array}{c}\text { Fungal } \\
\text { diseases }\end{array}$ & $\begin{array}{c}\text { Viral } \\
\text { diseases }\end{array}$ & $\begin{array}{c}\text { Insect } \\
\text { injuries }\end{array}$ \\
\hline Time $^{\mathrm{a}}$ & $56(3)$ & $61(2)$ & $0(4)$ & $64(1)$ \\
Space $^{\mathrm{b}}$ & $0(4)$ & $31(3)$ & $50(2)$ & $55(1)$ \\
Scale $^{\mathrm{c}}$ & $50(3)$ & $61(2)$ & $29(4)$ & $76(1)$ \\
Injury $^{\mathrm{d}}$ & $29(4)$ & $18(2)$ & $24(3)$ & $6(1)$ \\
\hline
\end{tabular}

a Percentage of studies conducted in 2 or more years. Numbers in parentheses indicate the rank order of the disease or injury groups based on decreasing proportions.

b Percentage of studies conducted in several locations. Numbers in parentheses indicate the rank order of the disease or injury groups based on decreasing proportions.

c Percentage of studies conducted on the scale of plots larger than $1 \mathrm{~m}^{2}$ or whole fields. Numbers in parentheses indicate the rank order of the disease or injury groups based on decreasing proportions.

d Standard deviation of the proportion of studies using inoculation, spontaneous infection, or chemical control. Numbers in parentheses indicate the rank order of the disease or injury groups based on increasing standard deviations.

Table 6. Number of studies of crop losses in different rice ecosystems in tropical Asia, classified by time span

\begin{tabular}{lcccc}
\hline $\begin{array}{l}\text { Duration of } \\
\text { experiments }\end{array}$ & $\begin{array}{c}\text { Irrigated } \\
\text { ecosystem }\end{array}$ & $\begin{array}{c}\text { Rain-fed low- } \\
\text { land ecosystem }\end{array}$ & $\begin{array}{c}\text { Deep-water } \\
\text { ecosystem }\end{array}$ & $\begin{array}{c}\text { Upland } \\
\text { ecosystem }\end{array}$ \\
\hline One season & 32 & 4 & 2 & 1 \\
Two seasons & 15 & 2 & 3 & 2 \\
More than two seasons & 19 & 9 & 6 & 3 \\
\hline
\end{tabular}

Table 7. Number of studies of crop losses in different rice ecosystems in tropical Asia, classified by the number of locations studied

\begin{tabular}{lcccc}
\hline $\begin{array}{l}\text { Number } \\
\text { of locations }\end{array}$ & $\begin{array}{c}\text { Irrigated } \\
\text { ecosystem }\end{array}$ & $\begin{array}{c}\text { Rain-fed low- } \\
\text { land ecosystem }\end{array}$ & $\begin{array}{c}\text { Deep-water } \\
\text { ecosystem }\end{array}$ & $\begin{array}{c}\text { Upland } \\
\text { ecosystem }\end{array}$ \\
\hline One location & 47 & 6 & 2 & 2 \\
More than one location & 19 & 9 & 9 & 4 \\
\hline
\end{tabular}

Table 8. Number of studies of crop losses in different rice ecosystems in tropical Asia, classified by the scale of experiments

\begin{tabular}{lcccc}
\hline Scale & $\begin{array}{c}\text { Irrigated } \\
\text { ecosystem }\end{array}$ & $\begin{array}{c}\text { Rain-fed low- } \\
\text { land ecosystem }\end{array}$ & $\begin{array}{c}\text { Deep-water } \\
\text { ecosystem }\end{array}$ & $\begin{array}{c}\text { Upland } \\
\text { ecosystem }\end{array}$ \\
\hline One plant or hill & 15 & 4 & 1 & 2 \\
Small plot $\left(<1 \mathrm{~m}^{2}\right)$ & 4 & 1 & 0 & 0 \\
Large plot $\left(>1 \mathrm{~m}^{2}\right)$ & 45 & 10 & 9 & 4 \\
Whole field & 2 & 0 & 1 & 0 \\
\hline
\end{tabular}

Table 9. Number of studies of crop losses in different rice ecosystems in tropical Asia, classified by methods of injury manipulation

\begin{tabular}{lcccc}
\hline $\begin{array}{l}\text { Method of injury } \\
\text { manipulation }\end{array}$ & $\begin{array}{c}\text { Irrigated } \\
\text { ecosystem }\end{array}$ & $\begin{array}{c}\text { Rain-fed low- } \\
\text { land ecosystem }\end{array}$ & $\begin{array}{c}\text { Deep-water } \\
\text { ecosystem }\end{array}$ & $\begin{array}{c}\text { Upland } \\
\text { ecosystem }\end{array}$ \\
\hline Inoculation & 26 & 3 & 2 & 1 \\
Spontaneous infection & 27 & 6 & 6 & 2 \\
Chemical control & 10 & 6 & 3 & 3 \\
\hline
\end{tabular}

Table 10. Representativeness of crop loss studies in different rice ecosystems in tropical Asia

\begin{tabular}{lcccc}
\hline $\begin{array}{l}\text { Representativeness } \\
\text { criterion }\end{array}$ & $\begin{array}{c}\text { Irrigated } \\
\text { ecosystem }\end{array}$ & $\begin{array}{c}\text { Rain-fed low- } \\
\text { land ecosystem }\end{array}$ & $\begin{array}{c}\text { Deep-water } \\
\text { ecosystem }\end{array}$ & $\begin{array}{c}\text { Upland } \\
\text { ecosystem }\end{array}$ \\
\hline Time $^{\mathrm{a}}$ & $52(4)$ & $73(3)$ & $82(2)$ & $83(1)$ \\
Space $^{\mathrm{b}}$ & $29(4)$ & $60(3)$ & $82(1)$ & $67(2)$ \\
Scale $^{\mathrm{c}}$ & $71(2)$ & $67(3)$ & $91(1)$ & $67(3)$ \\
Injury $^{\mathrm{d}}$ & $12(2)$ & $9(1)$ & $15(4)$ & $14(3)$ \\
\hline
\end{tabular}

a Percentage of studies conducted in 2 or more years. Numbers in parentheses indicate the rank order of the ecosystem groups based on decreasing proportions.

${ }^{b}$ Percentage of studies conducted in several locations. Numbers in parentheses indicate the rank order of the ecosystem groups based on decreasing proportions.

${ }^{c}$ Percentage of studies conducted on the scale of plots larger than $1 \mathrm{~m}^{2}$ or whole fields. Numbers in parentheses indicate the rank order of the ecosystem group based of decreasing proportions.

d Standard deviation of the proportion of studies using inoculation, spontaneous infection, or chemical control. Numbers in parentheses indicate the rank order of the ecosystem groups based on increasing standard deviations. ing more inclined to conduct long-term field experiments than bacteriologists and virologists). Most studies of virus diseases, especially rice tungro disease, appear to fall into two categories, either having been conducted on the scale of individual plants or having been conducted on the scale of whole fields or plots in years when the disease was frequent. This illustrates the need to gather data over a sufficient period of time (1), to avoid the possible bias associated with reports pertaining to "epidemic years" only, and at a scale which adequately reflects injurious effects. Further studies of crop losses due to phytopathogenic bacteria would be particularly useful, especially as they would allow researchers to ascertain whether available information can be extrapolated.

Comparison of studies conducted in the different rice ecosystems shows the need to better document yield losses in ecosystems other than the irrigated one. Many studies in the irrigated ecosystem were conducted in one year and one site only. This may be linked to the perception that this ecosystem, being highly controlled, is by essence homogeneous. There is evidence that the irrigated ecosystem is spatially and temporally heterogeneous in both patterns of cropping practices and injury profiles (10). The potential for extrapolation of a large fraction of the information pertaining to the irrigated rice ecosystem therefore deserves consideration. While the representativeness of studies conducted in the upland, rain-fed lowland, and deep-water ecosystems seems to be good, this cannot compensate for their small numbers, given the considerable ecological diversity of these ecosystems. Considerable research is still needed to document the current needs for disease management in these ecosystems. Perhaps more importantly, all four ecosystems are experiencing considerable social and ecological pressure and constraints. Patterns of rice-cropping practices are evolving or will have to evolve (2). Increasing the representativeness of yield loss data, especially over time (so as to identify key environmental trends) and over space (and thus including a range of patterns of cropping practices) will help to identify the needs of future rice production systems.

\section{ACKNOWLEDGMENTS}

The authors thank Peter Kenmore for useful comments on this manuscript.

\section{LITERATURE CITED}

1. Elazegui, F. A., Soriano, J., Bandong, J., Estorninos, L., Jonson, I., Teng, P. S., Shepard, B. M., Litsinger, J. A., Moody, K., and Hibino, H. 1990. Methodology used in the IRRI integrated pest survey. Pages 241-271 in: Crop Loss Assessment in Rice. International Rice Research Institute, Los Baños, Philippines.

2. Hossain, M. 1997. Rice supply and demand in Asia: A socioeconomic and biophysical analysis. Pages 263-280 in: Systems Approaches for Agricultural Development. Vol. 1. P. S 
Teng, M. J. Kropff, H. F. M. Ten Berge, J. B. Dent, F. P. Lansigan, and H. H. Van Laar, eds. Kluwer, Dordrecht, Netherlands.

3. James, W. C. 1974. Assessment of plant diseases and losses. Annu. Rev. Phytopathol. 12: 27-48

4. Johnson, K. B., Radcliffe, E. B., and Teng, P. S. 1986. Effects of interacting populations of $\mathrm{Al}$ ternaria solani, Verticillium dahliae, and the potato leafhopper (Empoasca fabae) on potato yield. Phytopathology 76:1046-1052

5. Khush, G. S. 1984. Terminology for rice growing environments. Pages 5-10 in: Terminology for Rice Growing Environments. International Rice Research Institute, Los Baños, Philippines.

6. Litsinger, J. A. 1992. Crop loss assessment in rice. Pages 1-65 in: Rice Insects: Management Strategies. E. A. Heinrichs and T. A. Miller, eds. Springer-Verlag, New York.

7. Madden, L. V. 1983. Measuring and modeling crop losses at the field level. Phytopathology 73:1591-1596

8. Putter, C. A. J. 1978. The management of epidemic levels of endemic diseases under tropical subsistence farming conditions. Pages 93103 in: Comparative Epidemiology: A Tool for Better Disease Management. J. Palti and J. Kranz, eds. PUDOC, Wageningen, Netherlands.

9. Sah, D. N., and MacKenzie, D. R. 1987. Meth- ods of generating different levels of disease epidemics in loss experiments. Pages 90-96 in: Crop Loss Assessment and Pest Management. P. S. Teng, ed. American Phytopathological Society, St. Paul, MN

10. Savary, S., Elazegui, F. A., Moody, K., Litsinger, J. A., and Teng, P. S. 1994. Characterization of rice cropping practices and multiple pest systems in the Philippines. Agric. Syst. 46:385-408.

11. Savary, S., Elazegui, F. A., Pinnschmidt, H. O., and Teng, P. S. 1997. Characterization of rice pest constraints in Asia: An empirical approach. Pages 83-98 in: Systems Approaches for Agricultural Development. Vol. 1. P. S. Teng, M. J. Kropff, H. F. M. Ten Berge, J. B. Dent, F. P. Lansigan, and H. H. Van Laar, eds. Kluwer, Dordrecht, Netherlands.

12. Savary, S., and Zadoks, J. C. 1992. Analysis of crop loss in the multiple pathosystem groundnut-rust-leaf spot. I. Six experiments. Crop Prot. 11:99-109.

13. Shane, W. W., and Teng, P. S. 1987. Generating the database for disease-loss modeling. Pages 82-89 in: Crop Loss Assessment and Pest Management. P. S. Teng, ed. American Phytopathological Society, St. Paul, MN.

14. Teng, P. S. 1990. Integrated pest management in rice: An analysis of the status quo with recommendation for action. Report to USAID Pesticide and Pest Management Project.
15. Teng, P. S. 1994. Integrated pest management in rice. Exp. Agric. 30:115-137.

16. Teng, P. S., Fischer, K. S., and Hossain, M 1995. Meeting the food challenges of the 21st century: The role of national and international rice research. Asian J. Trop. Biol. 1:1-21.

17. Teng, P. S., and Savary, S. 1992. Implementing the systems approach in pest management Agric. Syst. 40:237-264

18. Teng, P. S., and Shane, W. W. 1987. Crop losses due to plant pathogens. CRC Crit. Rev. Plant Sci. 2:21-47.

19. Teng, P. S., Torres, C. Q., Nuque, F. L., and Calvero, S. B. 1990. Current knowledge on crop losses in tropical rice. Pages 39-53 in Crop Loss Assessment in Rice. International Rice Research Institute, Los Baños, Philippines.

20. Van der Plank, J. E. 1963. Plant Diseases: Epidemics and Control. Academic Press, New York.

21. Zadoks, J. C. 1981. Crop loss today, profit tomorrow: An approach to quantifying production constraints and to measuring progress. Pages 5-11 in: Crop Loss Assessment Methods. Suppl. 3. L. Chiarappa, ed. CAB/FAO, Commonwealth Agricultural Bureau, Farnham Royal, U.K.

22. Zadoks, J. C., and Schein, R. D. 1979. Epidemiology and Plant Disease Management. Oxford University Press, New York. 